\title{
Barriers in Teaching Reading to ELLs and Ways of Overcoming Those Obstacles
}

\author{
Masoud Sadeghi \\ Department of English Language Teaching, Zanjan Branch, Islamic Azad University, Zanjan, Iran \\ Siros Izadpanah \\ Department of English Language Teaching, Zanjan Branch, Islamic Azad University, Zanjan, Iran
}

\begin{abstract}
Reading is one of the language skills, which is imperative in English learning and the requirement for exploring the effect of instructional strategies on instructing reading to the students have elevated in recent years. The purpose of this study was to determine what knowledgable and expert teachers of ELLs in the junior high schools make out as the barriers to the reading accomplishment of English students and what are the methods for conquering those barriers. The information were gathered from 60 successful teachers who taught in junior high schools of Zanjan, Iran. The successful educators were identified based on student accomplishment using purposive sampling. A Likert scale was utilized for the questionnaire. The successful teachers sort effective instructional tactics in the five constituent of reading and had the capacity to set up supplementary instructional tactics, barriers, and ways they overwhelmed barriers in an open-ended question on the questionnaire. The study was mixed-method research, which, as stated by Isaac and Michael (1995), is utilized " to explain systematically the realities and the features of a given population or domain of interest, factually and precisely ". The open-ended questions of questionnaire were intended to gather data in regards to barriers and methods for overcoming barriers for instructing reading to English students The findings uncovered that the participants' thoughts regarding barriers and ways of overcoming those barriers in instructing reading to English students.
\end{abstract}

Index Terms — reading, reading tactics, reading comprehension

\section{INTRODUCTION}

Recent developments in the field of teaching English have heightened the requirement for investigating the impact of effective instructional tactics on instructing reading to the students. Reading, as one of the four basic skills in language learning and teaching, is extremely significant as a language skill, as well as language input for other abilities to develop. In reality, many students feel that they can't productively and efficiently comprehend what they read. One principle reason representing this reality is that students have not gotten a handle on effective reading tactics.

Reading tactics or strategies mean "the intellectual procedures entangled when readers intentionally approach a content and make meaning of what they read " (Barnett, 1988, p.66). Specifically, reading tactics utilized by readers, their metacognitive awareness, and reading proficiency are firmly related. Basically, effective readers use more tactics in contrasted with less successful students and utilize them more frequently (Temur, T. U. R. A. N., \& Bahar, O. Z. G. E. ,2011). As well, better readers have higher metacognitive consciousness of their own strategy use, that cause associate increased reading skill (Baker \& Brown, 1984; Garner, 1987; Afflerbach, 2002 as cited in Hamdan et al., 2010, p.135).

Reading tactics are an imperative piece of a talented reader's occupation with content and his or her following accomplishment with that text. In favour of proficient reader, strategic reading is an mechanized process before, throughout and after reading (Brushaber, 2003, p.3). Reading strategies need to do with perceiving the object of reading, activating the interconnected background knowledge one has, focusing on key ideas, keep an eye on comprehension, and consequencing (Brown, Palincar, Armbruster, 1984; cited in Magno, 2008). They furthermore screen when they are having issues while reading. Because of the awareness of the complications they experience, they can modify their reading, for example, speeding up, slowing down, or stopping to read another text to get some background information about the current content (Pressley \& Gaskins, 2006, p.101). In any case, as poor readers don't have these basic reading procedures, they put strenuous effort into the substance to have the capacity to understand it. If taught a way to utilize and apply the reading ways, poor readers, as well, will finally end up plainly very important readers.

The present study endeavors to study the existing situation of using reading tactics among English teachers and learners of Zanjan middle schools. To be more exact, this study intends to examine the frequency of various sorts of reading tactics implemented by English teachers to instruct, and EFL students to get the hang of reading skill and comprehend the content and furthermore to identify the barriers in teaching those tactics and the ways the instructors use to overcome them. 
The purpose of this study is to determine what instructional tactics master educators of English language students (ELLs) in the junior high schools observe as most proficient for instructing reading to ELLs. For normal content teachers without a background in English as a second language, defining relevant teaching [tactics] for [English learners] pretends a significant and incomparable challenge. The results of the present examination can be similarly theoretically and practically significant in that the teachers ought to know about the best instructional tactics and apply them in their reading comprehension classes. At the best, they can increase their students' consciousness about the effective instructional tactics and persuade them to use in their practices of reading comprehension. The findings even can be significant for the understudies in that they can conquer the best instructional tactics so as to comprehend the readings proficiently.

Many researchers believe that the topic of effective instructional tactics have not been adequately investigated or that they have not conclusive findings or replies on the topic. Especially, they lack information concerning what expert teachers of ELLs in the junior high school identify as the obstacles to the reading accomplishment of English students and considerably further to date not any tactics suggested by the expert teachers that would be useful or considered barriers. In the researcher's opinion, the studies that have explored the barriers in teaching reading are not very many. Given the absence of research in this line there is plainly needed for studies that consolidate the barriers and methods for overcoming them in teaching reading. The purpose of the current study; consequently is to identify the barriers in teaching reading and methods for overcoming those obstacles from the expert teacher's perspective.

\section{LITERATURE REVIEW}

\section{A. Definition of Reading Comprehension Tactics}

Since late years, more consideration has been put on comprehension tactics and henceforth, a wide range of definitions were proposed to identify these strategies (Afflerbach \& Pressley, 1995; Barnett, 1988; Billman, Duke, Pearson, \& Strachan, 2011; Dehjalali, \& Izadpanah, 2017; Goudvis \& Harvey, 2007; Keene \& Zimmerman, 1997; Lienemann \& Reid, 2006; Oxford, 1990). In order to accurately identify reading comprehension tactics and determine strategic from nonstrategic readers, it wound up plainly fundamental to describe what is implied by the term " comprehension tactics" (Folman \& Sarig, 1990).

Along these lines, Garner (1987) characterized understanding strategies as "generally deliberate, planful exercises go up against by dynamic students, ordinarily to resolve perceived subjective disappointment" (p. 50). As indicated by The National Reading Panel report (2000), understanding strategies were seen as "specific methodology that guide understudies to end up plainly mindful of how well they are fathoming as they attempt to read" (NRP, 2000, p. 40). Brantmeier (2002) depicted comprehension strategies as "the understanding procedures that readers use keeping in mind the end goal to comprehend what they read" (p. 1). The expressions "activities," "procedures," and "processes" were utilized diversely to denote similar implications and were all performed by readers. Moreover, the results of these recommendations were contrastingly named however may allude to a similar expansive idea of comprehension: "cure perceived subjective disappointment" (p. 50), "well fathoming while at the same time reading" (p. 40), or "understand reading" (p. 1)

\section{B. Understanding What Strategic Readers Do}

Understanding what good readers do before, during, and after they read has turned into a basic essential to build up tactics for poor and non-skilled readers (Duke, 2001; Gallagher \& Pearson, 1983). To make sense of what nice and strategic readers do, Dole, Duffy, Pearson, and Roehler (1992) indicated that strategic readers associate what they apprehend to the new data that they need to find out, raise questions on what they scan and discriminate vital from lower ideas. Moreover, strategic readers are apt in coordinating information and observing their understanding. As acknowledged by Vacca (2002), strategic readers will use their previous learning before, during, and once they scan. whereas they're utilizing their previous data, they will confirm what's vital within the content, orchestrate, construe, raise queries, monitor understanding, and fix any faulty understanding. Correspondingly, Flood, Jensen, Lapp, and Squire (2003) recorded the accompanying highlights to recognize strategic readers from less or non-strategic readers: extricating meaning from the content, observing comprehension, addressing, reviewing, rereading, summarizing, evaluating, anticipating, and inferring. Moreover, Boardman, Klingner, and Vaughn (2007) used comparative methods and side " visualisation " to the list. additionally, Dole, Duffy, Pearson and Roehler (1991) found that strategic readers are often able to comprehend the reading piece virtually, inferentially, or in some contexts evaluatively. In different words, strategic readers will opt for what, when, and the way to utilize ways whereas reading.

\section{Recent Studies}

In a very recent study, Hayati and Jalilifar (2010) completed a test to explore the effect of reading abilities instruction passing on through TBLT on English reading perception of understudies. Forty-two understudies majoring in MBA were picked and randomly allocated to two groups as participants. The experimental group was taught four reading skills namely, scanning, skimming, 1 contextual clues, and critical reading through task-based language teaching, while the control group got the common translation instruction. Having taken a last examination, the members reading microskills were checked. Independent samples t-test was utilized to find possible differentiations between the two groups. 
The results uncovered that understudies in the experimental group having been instructed on reading abilities by means of TBLT outflanked their counterparts in the control group demonstrating a better academic performance and effective reading comprehension.

Khosravi (2000) attempted to look into the impact of scanning and skimming, as two reading tactics, on Iranian EFL understudies' reading rate and reading comprehension. The examination of the data demonstrated that scanning could fundamentally upgrade the understudies' both reading rate and reading perception, while in the meantime skimming represented huge change of the reading comprehension of the subjects. Shokrpour and Fotovatian (2009) conducted an experimental study to uncover the impacts of consciousness-raising of metacognitive tactics on a group of Iranian EFL understudies' reading comprehension. The results of this examination showed that contrasted with the control group, the experimental group showed a significant change in reading comprehension at the end of the treatment period.

McKeown, Beck, and Blake (2009) worked a two-year study in which institutionalized comprehension guideline for portrayals of two noteworthy strategies was composed and executed. The adequacy of the two experimental comprehension instructional conditions (Content and Strategies) and a control condition were taken a looked at. Content instruction focused understudies' thought on the substance of the content through open, meaning-based queries in connection with the content. In strategies instruction, understudies were demonstrated particular strategies to subsume their entrance to amid reading of the substance. The consequences of the investigation uncovered that there was no refinement between the presentations of the two experimental groups for some aspects of comprehension. However, for narrative recall and expository learning tests, the students following content instruction beated those following tactic instruction. In still another examination, Shang (2010) investigated a group of Taiwanese EFL students' utilization of three reading strategies (cognitive, metacognitive, compensation strategies), their perceived impact on the students' selfadequacy, and the connection between reading tactic use and perceived self-efficacy on their English reading comprehension. The results of this study demonstrated that metacognitive strategy was utilized most as often as possible followed by compensation strategy, and afterward cognitive strategy. In addition, a noteworthy positive relationship was found between the usage of reading strategies and impression of self-viability. Regardless, reading techniques were disconnected to reading achievement. Taking a look at studies reported above, one can reach the conclusion that the region of reading comprehension tactic instruction still requires additionally research about, particularly in an EFL context such as Iran and the present paper intends to explore the barriers in teaching reading tactics all the more profoundly by addressing a number of variables such as students' consciousness of reading tactics, the expansion of the scope of strategies utilized by students, and the effectiveness of reading comprehension strategy instruction, barriers and methods for conquering those obstacles from the instructors perspective.

\section{METHODOLOGY}

\section{A. Research Design}

The study was qualitative research, which is utilized to portray efficiently the certainties and the qualities of a given population or territory of interest, authentically and precisely. As this study inspected instructional strategies used by master educators and their view of organizing strategies, a qualitative study was the best way to deal with recognize the strategies supporting the instructors' endeavors in the classroom.

The quantitative part of the study enabled the researcher to gather data to distinguish barriers and recognize strategies to conquer recognized obstructions. The quantitative questions of the questionnaire were intended to gather data in regards to effective instructional strategies, perceived priority skills and utilization of strategies, barriers, and techniques for conquering boundaries for instructing reading to English students in the intermediate grades in junior high schools.

\section{B. Participants}

The population for this study was English instructors of junior high schools in Zanjan province. Members were picked in light of work at schools by the utilization of assessment of the five components of reading, and the suggestion of school principals who recognized the instructors as master junior high school teachers of English students in view of understudy accomplishment and reading levels. Purposive sampling was utilized to choose the members of the study. Extreme case sampling was the kind of purposive examining used to study the instructors whose understudies worked abnormally well (Isaac and Michael, 1995). There were a total of 69 junior high schools in Zanjan that met the criteria. The participants were teachers in junior high schools who were identified as experts in teaching reading to English learners.

\section{Materials}

\section{1. questionnaire}

The questionnaire queries were originated by the researcher based on the National Reading Panel's (NRP's) recommendation of the five elements of reading and therefore the literature review on English learners (see Appendix A). The questionnaire questions focused on instructional tactics for teaching reading to English learners in the junior high schools, intermediate skills, and methods to overcome barriers. The researcher created a Likert-scale questionnaire, which was distributed among participants to gather data. The questionnaire instrument contained questions about participants' perceptions considering instructional tactics, use, barriers, and strategies to beat declared barriers. 
Implementation of instructional tactics, time spent on instruction, and barriers were as well noted supported questionnaire results.

\section{Field Test}

With a specific end goal to guarantee the instrument was dependable, field tests were directed for the questionnaire. Two instructors who met the criteria as master educators took the questionnaire. Once the specialist dissected the information, he imparted the outcomes to the two educators who were a piece of the field test. After discussing the Likert-scale questionnaire, the questionnaire questions were reexamined and refreshed in view of the members' suggestions and results of questionnaire comes about. (Content validity ratio (CVR) and content validity index (CVI)).

\section{Procedure}

At the start of the study, the researcher sent the teachers a ranking-scale questionnaire. The questionnaire questions addressed the five elements of reading and were supported the literature review. When the questionnaires were completed, all data were analyzed. Teachers were asked to finish one questionnaire with both quantitative and qualitative data consequences about effective instructional tactics, the main target or priority of their instructional day, and overcoming barriers. After the data assortment, the researcher analyzed the responses to spot the instructional tactics and activities perceived as more vital to the teachers.

\section{RESULTS}

This study was designed to identify the barriers in teaching reading to ELLs and ways of overcoming those obstacles. To this end, the open-ended questions were developed to identify barriers and tactics to overcome those barriers (See Appendix A). The data from the open-ended questions were checked again, coded, and categorized based on participants' responses. Every respondent's write-in responses were scan and color-coded based on identified barriers, and methods to overwhelm barriers. Once all questionnaire were analyzed, patterns and themes associated with these areas were discovered and documented.

TABLE 4.1

THEMES, CATEGORIES AND CODES THAT TEACHERS PERCEIVED AS BARRIERS

\begin{tabular}{|c|c|c|}
\hline Codes & Categories & Themes \\
\hline Limited time to teach all five components & \multirow[t]{3}{*}{ Limited time } & \multirow[t]{3}{*}{ Time } \\
\hline Limited time to evaluate all students & & \\
\hline Lack of time to teach other skills & & \\
\hline Students fear of punishment by the teacher & \multirow[t]{2}{*}{ Concerns about lack of success in teaching } & \multirow[t]{4}{*}{ Anxiety } \\
\hline Disproportion of texts with students' knowledge level & & \\
\hline Lack of knowledge about teaching different tactics & \multirow[t]{2}{*}{ Lack of knowledge } & \\
\hline $\begin{array}{l}\text { Not preparing students to enter in teaching reading } \\
\text { section }\end{array}$ & & \\
\hline Lack of willingness in students to learn & \multirow[t]{3}{*}{ Lack of motivation } & \multirow[t]{4}{*}{ Motivation } \\
\hline Inaccuracies of students to what have been taught & & \\
\hline Frequent absence of students & & \\
\hline $\begin{array}{l}\text { Lack of positive feedback to teachers and students' } \\
\text { success }\end{array}$ & Lack of positive feedback & \\
\hline
\end{tabular}

Based on themes, categories and codes which were shown in the table above (Table 4.1), the teachers perceived the limited time of the classes as one of the barriers. Limited time of the classes made difficulties for teachers to teach all five components of the reading deeply. Also, lack of sufficient time made difficulties for teachers to evaluate the largest number of students of classes in proper times. Furthermore, the teachers had to teach other skills either, and limitation of time made difficulties for teachers.

Another barrier which teachers were faced was anxiety. Students' fear of punishment by the teachers, if they can't answer to the teachers' questions, made them anxious and they can't focus on what teacher taught. Also, sometimes the texts of books are not proportional with students' knowledge level. In addition, sometimes the teachers had not enough knowledge about all five components of reading and different tactics of teaching those components and this made anxiety which perceived as a barrier in teaching.

The next barrier in teaching of reading was lack of motivation in some students. They don't paid attention to what teacher taught, and consequently, they don't learn the components of reading. Also, frequent absence of students in classes made difficulties for teachers to teach appropriately. Finally, lack of positive feedback to those students who pay attention and learn what teacher taught, also lack of positive feedback to those teachers who had achievement in teaching components of reading, destroys their motivation and this perceived as another barrier to teach the reading components.

Holding remedial classes out of school time, were recommended by teachers to overcome the time limitation. Also, they recommended to divide the classes bya large number of students into two classes if possible in order to have enough time to teach all five components of reading and evaluate the students in each step.

Also, teachers recommended that, if the texts are not proportional with students' level of knowledge, they can want them to work on similar texts at home when they have more free time. In addition, giving positive feedback to students 
frequently and after every success and achievement, made them more motivated. Furthermore, giving positive feedback to teachers by the school headmasters, when the teachers have impressive achievement in teaching reading to students, made the teachers more motivated to put more energy in their classes.

\section{DISCUSSION}

Based on themes, categories and codes which were shown in the table (Table 4.1), the teachers perceived the limited time of the classes as one of the barriers. Limited time of the classes made difficulties for teachers to teach all five components of the reading deeply. Also, lack of sufficient time made difficulties for teachers to evaluate the largest number of students of classes in proper times. Furthermore, the teachers had to teach other skills either, and limitation of time made difficulties for teachers. Another barrier which teachers were faced was anxiety. Students' fear of punishment by the teachers, if they can't answer to the teachers' questions, made them anxious and they can't focus on what teacher taught. Also, sometimes the texts of books are not proportional with students' knowledge level. In addition, sometimes the teachers had not enough knowledge about all five components of reading and different tactics of teaching those components and this made anxiety which perceived as a barrier in teaching.

The next barrier in teaching of reading was lack of motivation in some students. They don't pay attention to what teacher taught, and consequently, they don't learn the components of reading. Also, frequent absence of students in classes made difficulties for teachers to teach appropriately. Finally, lack of positive feedback to those students who pay attention and learn what teacher taught, also lack of positive feedback to those teachers who had achievement in teaching components of reading, destroys their motivation and this perceived as another barrier to teach the reading components.

Other scholars expressed that, in the area of phonemic awareness and phonics, many students stir up letter shapes and sounds. The other researchers, Durgunoglu, Nagy and Hancin-Bhatt (1993); Izadpanah, Hatemi, \& Asadi (2016) clarified that, in addition to predicting second language phonological awareness, the phonological capacities that kids acquire in their native language interference in their ability to perceive words in English. Also, phonological awareness is commonly observed to be a critical component of literacy improvement (Catts, Hogan \& Little, 2005; Gholami, Alavinia, \& Izadpanah, 2015; Jorm, McClean \& Share, as cited in Ehri, 2001; Murray \& Stahl 1994).

In the area of phonic, one primary contention from educators was that reading is a way to assist find what is critical to the person in a youthful child. An instructor trusted that orderly instruction is inconvenient and that teaching reading is spontaneous. Another educator had similar perspectives of how teaching reading isn't an arranged action, yet rather can be instructed in minutes. Besides, young children are not prepared to learn letters and sounds but rather to ask learning the sounds by listening to others speak.

\section{CONCLUSION}

This study explored the barriers in teaching reading to ELLs as perceived by successful junior high schools' educators and methods for overcoming those obstacles. Staff improvement for innovative and existing teachers ought to be directed to guarantee they possess the skills obligatory to teach all students to read. The preparation must review the meaning of phonemic awareness, as this is frequently confused for phonics. Giving the definition and examples of phonemic awareness instructional strategies, lessons, and exercises should to be a part of the preparation. It would be advantageous for teachers to generate one lesson on each of the following: segmenting and blending sounds, identifying the quantity of sounds in words, recognizing rhyming words, making rhyming words, and syllabication .

It is critical to begin students in phonics instructing in elementary school since understudies who have phonics teaching early have a propelled reading ability than those understudies who don't have a strong basis in their initial education as it is expressed in Ehri, Nunes, Stahl \& Willows' investigation (2001).

Letter reversals (when students misperceive the shape or sound of one letter for another letter, for example, mistaking $d$ for $b$ ) are frequent among children in the early grades. Concentrate on one letter at a time, teaching the first letter shape (e.g., $b$ ) in a variety of ways until the point when the student can recognize it promptly. At that point, instruct the student another letter or two, reviewing and reinforcing the first letter somewhat more. Finally, focus on the other letter (e.g. d) completely.

\section{ACKNOWLEDGEMENTS}

We feel indebted to many who assisted us in completing this study from colleagues who meticulously supervised the whole attempt, generously made comments on each part and constantly encouraged us in our efforts to fulfill the job to students who helped us to actualize the concepts of the research.

\section{REFERENCES}

[1] Afflerbach, Peter. (2007). Understanding and Using Reading Assessment K-12. University of Maryland: College Rark.

[2] Baker, L., \& Brown, A. L. (1984). Metacognitive skills and reading. Handbook of reading research, 1(353), V394. Lawrence Erlbaum Associates, Publishers. Mahwah, New Jersey. 
[3] Barnett, M. A. (1988). Reading through context: How real and perceived strategy use affects L2 comprehension. The Modern Language Journal, 72(2), 150-162. https://doi.org/10.1016/j.sbspro.2014.12.034.

[4] Brantmeier, C. (2002). Second Language Reading Strategy Research at the Secondary and University Levels: Variations, Disparities and Generalizability. The Reading Matrix, 2 (3), 1 - 14 . Retrieved from http://www.readingmatrix.com/articles/braintmeier/article.pdf. Retrieved on September, 6, 2017.

[5] Brown, A., \& Palincsar, A. (1989). Guided cooperative learning and individual acquisition. In L. B. Resnil (Ed.). Knowing, learning, and instruction: Essays in honor of Robert Glaser (pp. 393- 451). Hillsdale, NJ: Erlbaum.

[6] Brushaber, T. (2003). Teaching comprehension through a comprehension strategy framework. Southwest Texas State University, 1-19. Retrieved December 3, 2010, from http://www.eric.ed.gov/PDFS/ED477160.pdf.

[7] Dehjalali, M. R., \& Izadpanah, S. (2017). The Study of Vocabulary Awareness Effect on Intermediate Language Learners' Depth of Vocabulary Knowledge in Genuine Persian Texts. International Journal of English Linguistics, 7(1), 183-185.

[8] Dole, J. A., Duffy, G. G., Roehler, L. R., \& Pearson, P. D. (1991). Moving from the old to the new: Research on reading comprehension instruction. Review of Educational Research, 61(2), 239-264.

[9] Duke, N., \& Pearson, D. (2001). Reading comprehension: Strategies that work. Retrived from http://www.jstor.org/stable/42748663?seq=1\#page_scan_tab_contents. Retrieved on November, 25, 2011.

[10] Duke, N., Pearson, D., Strachan, S., \& Billman, A. (2011). Essential elements of fostering and teaching reading comprehension. What research has to say about reading instruction, 4, 51-93.

[11] Ehri, L. C., Nunes, S. R., Stahl, S. A., \& Willows, D. M. (2001). Systematic phonics instruction helps students learn to read: Evidence from the National Reading Panel's meta-analysis. Review of educational research, 71(3), 393-447.

[12] Ehri, L. C., Nunes, S. R., Willows, D. M., Schuster, B. V., Yaghoub-Zadeh, Z., \& Shanahan, T. (2001). Phonemic awareness instruction helps children learn to read: Evidence from the National Reading Panel's meta-analysis. Reading research quarterly, $36(3), 250-287$.

[13] Flood, J., Lapp, D., Squire, J. R., \& Jensen, J. M. (2003). Handbook of research on teaching the English language arts. Lawrence Erlbaum Associates, Inc., Publishers, 10 Industrial Ave., Mahwah, NJ 07430-2262.

[14] Folman, S., \& Sarig, G. (1990). Intercultural rhetorical differences in meaning construction.

[15] Garner, R. (1987). Metacognition and reading comprehension. Ablex Publishing. New York City, New York, USA.

[16] Gholami, J., Alavinia, P., \& Izadpanah, S. (2015). The Study of the Effect of Educational Level of Students and English Language Teachers' Awareness on True and False Cognates in Iran. Sino-US English Teaching, 12(7), 471-478.

[17] Hamdan, A. R., Ghafar, M. N., Sihes, A. J., Atan, S. B. (2010). The cognitive and metacognition reading strategies of foundation course students in Teacher Education Institute in Malaysia. European Journal of Social Sciences, 13(1), 133-144.

[18] Harvey, S., \& Goudvis, A. (2007). Strategies that work: Teaching comprehension for understanding and engagement. Stenhouse Publishers. Portland, Maine.

[19] Hayati, M., \& Jalilifar, A. (2010). Task-based teaching of micro-skills in an EAP situation. Taiwan International ESP Journal, 2(2), 49-66.

[20] Hogan, T. P., Catts, H. W., \& Little, T. D. (2005). The Relationship Between Phonological Awareness and ReadingImplications for the Assessment of Phonological Awareness. Language, Speech, and Hearing Services in Schools, 36(4), 285-293

[21] Isaac, S., \& Michael, W. B. (1995). Handbook in research and evaluation: A collection of principles, methods, and strategies useful in the planning, design, and evaluation of studies in education and the behavioral sciences. San Diego, CA: EdITS.

[22] Izadpanah, S., Hatemi, M., \& Asadi, F. (2016). The Study of Learners' Educational Level and Their Knowledge of True Cognate Words in Iran. Journal of Language Teaching and Research, 7(5), 985-992.

[23] Kashef, S. H., Viyani, A., Ghabool, N., \& Damavand, A. (2012). Examing the Effect of a Learning-centered Reading Instruction on Iranian Students' Reading Comprehension: An Action Research. English Language Teaching, 5(10), 58.

[24] Khosravi, A. A. (2000). The effect of scanning and skimming on the rate of and reading comprehension of Iranian EFL learners. Unpublished master's thesis). Shiraz University, Iran.

[25] Klingner, J. K., Vaughn, S., \& Boardman, A. (2007). Teaching reading comprehension to students with learning difficulties, 2/E. Guilford Publications. New York City, New York, United States.

[26] Magno, C. (2008). Reading strategy, amount of writing, metacognition, metamemory, and apprehension as predictors of English written proficiency. Asian EFL Journal, 29. Retrieved January 3, 2011, from http://www.asian-efljournal.com/pta_July_08_cm.php.

[27] McKeown, M. G., Beck, I. L., \& Blake, R. G. (2009). Rethinking reading comprehension instruction: A comparison of instruction for strategies and content approaches. Reading Research Quarterly, 44(3), 218-253.

[28] Nagy, W. E., García, G. E., Durgunoğlu, A. Y., \& Hancin-Bhatt, B. (1993). Spanish-English bilingual students' use of cognates in English reading. Journal of Reading Behavior, 25(3), 241-259.

[29] National Reading Panel (US), National Institute of Child Health, \& Human Development (US). (2000). Report of the national reading panel: Teaching children to read: An evidence-based assessment of the scientific research literature on reading and its implications for reading instruction: Reports of the subgroups. National Institute of Child Health and Human Development, National Institutes of Health.

[30] Pearson, P. D., \& Gallagher, M. C. (1983). The instruction of reading comprehension. Contemporary educational psychology, 8(3), 317-344.

[31] Pressley, M., \& Afflerbach, P. (1995). Verbal protocols of reading: The nature of constructively responsive reading. Routledge.

[32] Pressley, M. \& Gaskins, I. W. (2006). Metacognitively competent reading comprehension is constructively responsive reading: How can such reading be developed in students? Metacognition Learning, 1, 99-113.

[33] Lienemann, T. O., \& Reid, R. (2006). Self-regulated strategy development for students with learning disabilities. Teacher Education and Special Education, 29(1), 3-11.

[34] Roehler, H. W. (1992). Correlation, composition, areal distribution, and thickness of Eocene stratigraphic units, greater Green River basin, Wyoming, Utah, and Colorado (No. 1506-E). 
[35] Shang, H. F. (2010). Reading strategy use, self-efficacy and EFL reading comprehension. Asian EFL Journal, 12(2), 18-42.

[36] Shokrpour, N., \& Fotovatian, S. (2009). Effects Of Consciousness Raising Of Metacognitive Strategies On Efl Students'reading Comprehension. ITL. International journal of applied linguistics A. 2009, $\mathrm{n}^{\circ}$ 157, [75-92 [17 p.]] [bibl. : 2 p.1/4]

[37] Stahl, S. A., \& Murray, B. A. (1994). Defining phonological awareness and its relationship to early reading. Journal of educational Psychology, 86(2), 221-234.

[38] Temur, T. U. R. A. N., \& Bahar, O. Z. G. E. (2011). Metacognitive awareness of reading strategies of Turkish learners who learn English as a foreign language. European Journal of Educational Studies, 3(2), 421-427.

[39] Vacca, R. T. (2002). Making a difference in adolescents' school lives: Visible and invisible aspects of content area reading. What research has to say about reading instruction, 3, 184-204.

[40] Keene, E. O., \& Zimmermann, S. (1997). Mosaic of thought: Teaching comprehension in a reader's workshop. Heinemann, 361 Hanover Street, Portsmouth, NH 03801-3912.

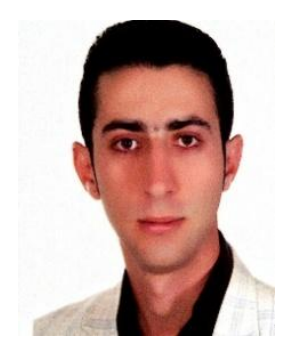

Masoud Sadeghi has an MA from Zanjan branch, Islamic Azad University, Zanjan, Iran and is currently teaching at junior high schools of Zanjan, Iran.

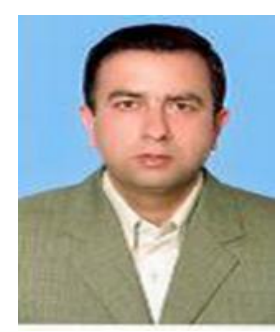

Siros Izadpanah has a Ph. D in applied Linguistics and the author of many articles in English Teaching. He has written seven university books and lectured in over eight international conferences. He was also the keynote speaker in India English conference. He is also the referee of some International Journals. 